UDC 612.3.014.12.7

\title{
DETERMINATION OF EQUIVALENT QUANTITIES OF ELECTROMAGNETIC FIELD IN MASSIVE FERROUS DETAILS OF ELECTRIC EQUIPMENT UNDER STRONGLY VARYING LOADS
}

\section{ZINOVKIN V.V}

BLYZNIAKOV O.V.

Sci.D, Associate professor, Professor of the Electric Drive and Commercial Plant Automation department of the Zaporozhye National Technical University, Zaporozhye, Ukraine, e-mail: znvvv@ukr.net;

Ph.D, Associate professor, Associate professor of the Electric and Electronic department of the Zaporozhye National Technical University, Zaporozhye, Ukraine, email: blizn1953@gmail.com;

Purpose. To derive the relationships for calculating determination of equivalent quantities for electromagnetic field in massive ferrous bodies at strongly varying loads.

Methodology. We have applied methodological fundamentals of skin-effect theory for massive ferrous bodies combined with methods of mathematical physics as well as physical and computer simulation.

Findings. We have found the mathematical expressions for the equivalence ratios allowing calculate basic electromagnetic field quantities, such as magnetic flux and losses, in massive ferrous bodies under strongly varying loads. Their adequacy is confirmed by research on physical and computer models, as well as existing computational procedures of the additional losses in the massive units of energy-intensive electrical equipment for special purposes.

Originality. For the first time, we have established mathematical dependencies between skin losses and magnetic flux in massive ferrous body and total and individual harmonic distortion of periodically varying magnetic and electric fields. Found dependences are the basis for the development of refined computational procedures for determining the parameters of the electromagnetic field in massive ferromagnetic elements of electrical equipment under stronglyvarying loads.

Practical value. The use of derived expressions for the equivalence ratios enable successfully solve the problems aimed to optimize constructive components when designing electrical equipment for supplying consumers with stronglyvarying behavior of the load.

Keywords: electromagnetic field; strongly-varying load; massive ferrous body; skin-effect; skin magnetic flux; skin losses; equivalence ratio; composition of high harmonics.

\section{INTRODUTION}

Massive details are integral constructive elements of electric equipment, including power-intensive equipment for technology applications. Such details are usually made of ferromagnetic materials and intended to provide electrodynamic stability and optimal functioning of the equipment in different technological and emergency conditions. In service process, constructive elements of electric equipment, including massive ferrous details, are stressed by alternating stray magnetic fields causing additional losses because of strong skin-effect [1], [4], [9], [13].

\section{ANALYSIS OF LAST RESEARCHES}

For the sake to select optimal engineering solutions, these phenomena are carefully analyzed at all development stages of electric equipment. The electromagnetic calculations, being performed in the process, are made with use of available engineering procedures [3], [8], but in engineering experience such problems are solved, for the most part, by experimental way using, for example, scale simulation [6], [10]-[12].

However, when we deal with strongly-varying behav- ior of the load, the analysis of electromagnetic phenomena significantly complicates because of availability of high harmonic, DC and DC pulsating components [2], [7], [9], [13], [14]. It, in turn, complicates investigations and evaluation of losses in constructive components of electric equipment. Therefore, the use of conventional engineering calculation procedures is in this case inadmissible in terms of real service conditions. Especially it is related to specialpurpose transformer equipment and tap-changers, in particular, for HVDC power transmission lines (power super highway) and back-to-back stations, as well as supplying power-intensive electric technological installations, such as arc steel melting furnaces, and other applications. [3], [5], [6], [10], [14].

Available high harmonic, DC and DC pulsating components lead to significant increase in losses and local heating of constructive details in comparison with the case, when the electromagnetic field is sine time-varying. Direct component and individual inrushes result in change of the ferromagnetic magnetic permeability [7], [9], [15][18].

It is well-known that when we deal with strong skineffect, electromagnetic field in ferrous bodies is concentrated into thin superficial layer. With, the dimensions of 
massive details of electric equipment, as a rule, in far excess of equivalent penetration depth of electromagnetic wave. By this why, to sufficient for engineering practice accuracy the constructive complex-shaped components can be considered as ferromagnetic half-space [6]-[9].

In this work, it is shown that electromagnetic field quantities in massive ferrous bodies (constructive equipment components) under strongly-varying behavior of the load can be determined by equivalent averaged magnetic field of increased intensity or equivalent frequency.

\section{FORMULATION OF THE WORK PURPOSE}

The work purpose is the development of engineering calculation procedures concerning to electromagnetic field quantities in massive ferrous constructive components of equipment under strongly-varying behavior of the load.

\section{EXPOUNDING THE MAIN MATERIAL AND RESULTS ANALYSIS}

Analytical statement of the problem and research procedure. It is known that when we deal with massive ferrous bodies the electromagnetic field on their surface indicates internal physical phenomena. It enables to use external characteristics of the electromagnetic field without researching proper ferrous body. Therefore, in this case researches and evaluation of the electromagnetic field quantities are performed by means of time-averaged rms values of

- magnetic field intensity expressed as:

$$
H_{\xi(0)}=\left\{\frac{1}{T_{1}} \int\left[\sum_{0}^{T_{1}}\left[\sum_{v=1}^{N} H_{\mathrm{mv}} \sin \left(\omega_{v} t+\varphi_{v H}\right)\right]^{2} d t\right\}^{0,5} ;\right.
$$

- electric field intensity expressed as:

$$
E_{\xi(0)}=\left\{\frac{1}{T_{1}} \int_{0}^{T_{1}}\left[\sum_{v=1}^{N} E_{\mathrm{m} v} \sin \left(\omega_{v} t+\varphi_{v E}\right)\right]^{2} d t\right\}^{0,5}
$$

- skin magnetic flux expressed as:

$$
\Phi_{\xi(0)}=\left\{\frac{1}{T_{1}} \int_{0}^{T_{1}}\left[\sum_{v=1}^{N} \Phi_{\mathrm{m} v} \sin \left(\omega_{v} t+\varphi_{v \Phi}\right)\right]^{2} d t\right\}^{0,5},
$$

where $T_{1}$ is the first harmonic cycle duration; $\omega$ is angle the frequency; $t$ is the time; $\varphi$ are the initial phases; $v$ are the number of harmonic component; $H_{\mathrm{mv}}, E_{\mathrm{mv}}, \Phi_{\mathrm{mv}}$ are the amplitude values of harmonic components for magnetic and electric field intensities as well as the skin magnetic flux.

Skin impedance $Z_{\xi}$ and skin losses $Q_{\xi}$ of massive ferrous body for the case being considered, as well as the magnetic field intensity are correlated between them by the following relationships [1], [6]-[8]:

$$
\begin{gathered}
E_{\xi(0)}=\sum_{v=1}^{N} \omega_{1} v \Phi_{v(0)}=\omega_{\mathrm{eq}} \Phi_{\xi(0)} ; \\
\Phi_{\xi(0)}=\sum_{v=1}^{N}\left[\mu \cdot\left(\omega_{1} v \sigma\right)^{-1}\right]^{0,5} \cdot H_{\xi(0)} ; \\
Q_{\xi}=\sum_{v=1}^{N}\left[\left(\omega_{1} v \mu\right) 2 \sigma^{-1}\right]^{0,5} \cdot H_{\xi(0)}^{2} ; \\
Z_{\xi}=E_{\xi(0)} \cdot H_{\xi(0)}^{-1}=\left[\left(\omega_{1} v \mu\right) \cdot \sigma^{-1}\right]^{0,5},
\end{gathered}
$$

where $\sigma$ is the electric conductivity of the ferromagnetic material; $\mu$ is the magnetic permeability of the ferromagnetic material; $\omega_{1}$ is the angle frequency of the first harmonic component of the electromagnetic field.

It should be pointed out here that magnetic permeability is non-linear characteristic of the ferromagnetic. However, in our case at the beginning the electromagnetic processes are considered in linear ferromagnetic, and then derived findings will be extended to real massive ferrous element.

An analysis of the equalities (4-7) shows the possibility to represent the quantities of the electromagnetic field, caused by strongly varying behavior of the load, with harmonic (equivalent) quantities. The essence of such approach implies that the magnetic field on the surface of the body being considered is substituted by harmonic (equivalent) time-varying magnetic field with the first harmonic frequency or increased (equivalent) frequency so that the equalities

- for the electric field intensities:

$$
\begin{gathered}
E_{\xi(0)}\left(H_{\xi(0)}\right)=E_{(0)}\left(H_{\xi}\right)_{\omega=\omega_{\mathrm{eq} E}} \\
\text { or } \\
E_{\xi(0)}\left(H_{\xi(0)}\right)=\left.E_{(0)}\left(\omega_{\mathrm{eq}}\right)\right|_{H=H_{\mathrm{eq} E}}
\end{gathered} ; ;
$$

- for the skin magnetic fluxes:

$$
\left.\begin{array}{rl}
\Phi_{\xi(0)}\left(H_{\xi(0)}\right)= & \Phi_{(0)}\left(H_{\mathrm{eq}}\right)_{\omega=\omega_{\mathrm{eq} \Phi}} \\
& \text { or } \\
\Phi_{\xi(0)}\left(H_{\xi(0)}\right)= & \left.\Phi_{(0)}\left(\omega_{\mathrm{eq}}\right)\right|_{H=H_{\mathrm{eq} \Phi}}
\end{array}\right\} ;
$$

- for the specific skin losses:

$$
\left.\begin{array}{c}
Q_{\xi(0)}\left(H_{\xi(0)}\right)=\left.Q_{(0)}\left(H_{\mathrm{eq}}\right)\right|_{\omega=\omega_{\mathrm{eq} Q},} \\
\text { or } \\
Q_{\xi(0)}\left(H_{\xi(0)}\right)=\left.Q(\omega)\right|_{H=H_{\mathrm{eq} Q}}
\end{array}\right\},
$$

will be fulfilled.

In expressions (8-10): $\omega_{\mathrm{eq} E} \neq \omega_{\mathrm{eq} \Phi} \neq \omega_{\mathrm{eq} Q}$ are the 
equivalent frequencies; $H_{\mathrm{eq} E} \neq H_{\mathrm{eq} \Phi} \neq H_{\mathrm{eq} Q}$ are equivalent magnetic field intensities. In the case of linear ferromagnetic, at sine-varying magnetic field with frequency of first harmonic, the skin-effect quantities are described by the following equalities [1], [6]:

$$
\begin{gathered}
Q\left(H_{1(0)}\right)=\left[\left(\omega_{1} \mu\right)(2 \sigma)^{-1}\right]^{0,5} \cdot H_{1(0)}^{2} ; \\
E_{(0)}=\omega_{1} \mu\left[\left(\omega_{1} \sigma \mu\right)^{-1}\right]^{0,5} \cdot H_{1(0)}=\left[\omega_{1} \mu(\sigma)^{-1}\right]^{0,5} \cdot H_{1(0)} ; \\
\Phi_{(0)}=\left[\mu\left(\omega_{1} \sigma\right)^{-1}\right]^{0,5} \cdot H_{1(0)} .
\end{gathered}
$$

Determining equivalence ratios. The equivalence ratios or coefficients of equivalence for strongly-varying electric and magnetic field intensities, skin flux and skin losses are found from the following equalities:

$$
\begin{aligned}
& H_{\mathrm{eq} E(0)}=\left.H_{(0)} \cdot \beta_{i E}\right|_{\omega=\omega_{1} ; H_{(0)}=H_{\xi(0)}}, \\
& H_{\mathrm{eq} \Phi(0)}=\left.H_{(0)} \cdot \beta_{i \Phi}\right|_{\omega=\omega_{1} ; H_{(0)}=H_{\xi(0)}}, \\
& H_{\mathrm{eq} Q(0)}=\left.H_{(0)} \cdot \beta_{i Q}\right|_{\omega=\omega_{1} ; H_{(0)}=H_{\xi(0)}},
\end{aligned}
$$

where $\beta_{i E}, \beta_{i \Phi}, \beta_{i Q}$ are the equivalence ratios for the electric field intensity, skin flux and losses, respectively.

The equivalence ratios are also determined basing upon the fractional contribution of the harmonic components included by the electromagnetic field predetermined on the surface of the massive ferrous body. Besides, the magnetic field intensity is to be represented by averaged quantities for the cycle of the first harmonic component according to expression (1).

From equalities (14-16) it follows that each quantity of the electromagnetic field:

$$
E_{\xi(0)}\left(H_{\xi(0)}\right), \Phi_{\xi(0)}\left(H_{\xi(0)}\right), Q_{\xi}\left(H_{\xi(0)}\right)
$$

is corresponded by its own equivalence ratio or coefficient of equivalence. This situation enables to reduce the calculation of its quantities to the calculation of corresponding equivalence ratios. Accordingly, these quantities can be expressed through the equivalence ratios and represented by the following equations:

- for the electric field intensity:

$$
\left.\begin{array}{l}
E_{\xi(0)}\left(H_{\xi(0)}\right)=\left.E_{(0)}\left(H_{(0)}\right) \cdot \beta_{i E}\right|_{\omega=\omega_{1}, H_{\xi(0)}=H_{(0)}} \\
E_{\xi(0)}\left(H_{\xi(0)}\right)=\left.E_{(0)}\left(H_{(0)}\right) \cdot \delta_{\mathrm{e} \Phi}\right|_{\omega=\omega_{\mathrm{eq}}, H_{\xi(0)}=H_{(0)}}
\end{array}\right\} ;
$$

- for the skin magnetic flux:

$$
\left.\begin{array}{l}
\Phi_{\xi(0)}\left(H_{\xi(0)}\right)=\left.\Phi_{\xi(0)}\left(H_{(0)}\right) \cdot \beta_{i \Phi}\right|_{\omega=\omega_{1}, H_{\xi(0)}=H_{(0)}} \\
\Phi_{\xi(0)}\left(H_{\xi(0)}\right)=\left.\Phi_{\xi(0)}\left(H_{(0)}\right) \cdot \delta_{\mathrm{ee} \Phi}\right|_{\omega=\omega_{\mathrm{eq}}, H_{\xi(0)}=H_{(0)}}
\end{array}\right\} ;
$$

- for the skin losses:

$$
\left.\begin{array}{l}
Q\left(H_{\xi(0)}\right)=\left.Q\left(H_{(0)}\right) \cdot \beta_{i Q}\right|_{\omega=\omega_{1}, H_{\xi(0)}=H_{(0)}} \\
Q\left(H_{\xi(0)}\right)=\left.Q\left(H_{(0)}\right) \cdot \delta_{\mathrm{eq} Q}\right|_{\omega=\omega_{\mathrm{eq}}, H_{\xi}(0)=H_{(0)}}
\end{array}\right\} .
$$

The equivalence ratios are calculated basing upon the spectral composition of one of strongly-varying electromagnetic field quantities for the ferrous body being considered.

The expressions derived for the equivalence ratios of the electromagnetic field quantities for a massive ferrous body under strongly-varying loads are represented in tables 1 and 2 .

As seen the equivalent quantities allow simplify simulation of electromagnetic processes and engineering calculations of skin losses in massive constructional details of electrical and electric-technological equipment subjected by action of the electromagnetic field caused by stronglyvarying loads.

The equivalence ratios indicate the effect of each harmonic, contained by the magnetic field, on its parameters.

Table 1. The expressions for the equivalence ratios of the magnetic field intensity during the researches of the electromagnetic field quantities in massive components of structural steels at strongly-varying loads.

\begin{tabular}{|c|c|c|c|}
\hline \multirow{2}{*}{$\begin{array}{c}\text { Equivalence } \\
\text { ratios }\end{array}$} & \multicolumn{2}{|c|}{ The expressions for the equivalence ratios of the electromagnetic field quantities } \\
\cline { 2 - 4 } & magnetic & electric & skin flux \\
\hline$\beta_{i Q}$ & $\left(\sum_{v=1}^{N} v^{0,5} \cdot \gamma^{2}\right)^{0,5}$ & $\delta_{\omega Q} \cdot \sum_{v=1}^{N} \gamma_{E v}^{2} \cdot v^{0,5}$ & $\left(\sum_{v=1}^{N} \gamma_{\Phi v}^{2} \cdot v^{3 / 2}\right) \cdot \delta_{\omega \Phi}^{-1}$ \\
\hline$\beta_{i E}$ & $\left(\gamma_{H v}^{2} \cdot v\right)^{0,5}$ & {$\left[\sum_{v=1}^{N}\left(\gamma_{E v}^{2}: v\right)^{-1}\right]^{0,5}$} & $\left(\sum_{v=1}^{N} \gamma_{\Phi v} \cdot v^{2}\right) \cdot \delta_{\omega \Phi}^{-1}$ \\
\hline$\beta_{i \Phi}$ & $\left(\sum_{v=1}^{N} v^{0,5} \cdot \gamma_{H v}\right)^{-1}$ & $\left(\delta_{\omega E} \cdot \sum_{v=1}^{N} \gamma_{E v}^{2} \cdot v^{-2}\right)^{0,5}$ & $\sum_{v=1}^{N} v \cdot \gamma_{\Phi v}$ \\
\hline
\end{tabular}


Table 2. The expressions for the equivalence ratios of the frequency during the researches of the electromagnetic field quantities in massive components of structural steels at strongly-varying loads

\begin{tabular}{|c|c|c|c|}
\hline \multirow{2}{*}{$\begin{array}{c}\text { Equivalence } \\
\text { ratios }\end{array}$} & \multicolumn{3}{|c|}{ The expressions for the equivalence ratios of the electromagnetic field quantities } \\
\cline { 2 - 4 }$\delta_{\omega Q}$ & magnetic & electric & skin flux \\
\hline$\left.\sum_{v=1}^{N} v^{0,5} \cdot \gamma^{2}\right)^{2}$ & $\left(\sum_{v=1}^{N} \gamma_{E v}^{2} \cdot v^{-0.5}\right)^{2} \cdot \delta_{\omega E}$ & $\left(\gamma_{\omega v} \cdot v^{3 / 2}\right)^{2} \cdot \delta_{\omega \Phi}$ \\
\hline$\delta_{\omega E}$ & $\left(\sum_{v=1}^{N} v_{H N}^{2} \cdot \gamma^{-1}\right)^{-1}$ & $\left(\sum_{v=1}^{N} \gamma_{E v}^{2} \cdot v^{-2}\right)^{-1}$ & $\sum_{v=1}^{N} \gamma_{\Phi v}^{2} \cdot v$ \\
\hline$\delta_{\omega \Phi}$ & $\sum_{v=1}^{N} \gamma_{H v}^{2} \cdot v$ & $\left(\sum_{v=1}^{N} \gamma_{E v}^{2} \cdot v^{-1}\right)^{-1}$ & $\left(\sum_{v=1}^{N} \gamma_{\Phi v}^{2} \cdot v^{2}\right) \cdot \delta_{\omega \Phi}$ \\
\hline
\end{tabular}

Influence of high harmonic components. In practice every so often, there are the cases, when it is known harmonic composition of one of the quantities of the electromagnetic field: either magnetic or electric field intensity or skin magnetic flux, but harmonic composition of other one is required.

Therefore, it should be represented the relation between the equivalence ratios and high harmonic components contained by the strongly-varying electromagnetic field.

The dependences between high harmonic components and skin-effect quantities: magnetic and electric fields as well as skin flux can be derived in an explicit form. For other electromagnetic field quantities, such as skin impedance and losses, such dependencies are resulted from influence of strongly-varying loads. By this why the influence of high harmonics will be estimated through the ratio between each harmonic component and averaged parameter being considered for the cycle.

For the magnetic field intensity:

$$
\left.\begin{array}{l}
\gamma_{E v}=E_{v(0)}: E_{\xi(0)}\left(H_{\xi(0)}\right) \\
\gamma \Phi=\Phi_{v(0)}: \Phi_{\xi(0)}\left(H_{\xi(0)}\right) \\
\gamma_{H v}=H_{v(0)}: H_{\xi(0)} .
\end{array}\right\},
$$

For the electric field intensity:

$$
\gamma_{E v}^{2}=\gamma_{H v}^{2} v \cdot\left(\sum_{v=1}^{N} v \lambda_{H v}^{2}\right)^{-1}=\gamma_{H v} \cdot\left(v \cdot \delta_{\omega H}^{-\cdot}\right)^{0,5},
$$

For the skin flux:

$$
\begin{aligned}
& \gamma_{E v}^{2}=\gamma_{\Phi v}^{2} v^{2} \cdot\left(\sum_{v=1}^{N} v \lambda_{\Phi v}^{2}\right)^{-1}= \\
& =\gamma^{2} \cdot v^{2} \cdot \delta_{\omega \Phi}^{-}=\left(\gamma_{\Phi v} \cdot v\right)^{2} \cdot\left(\delta_{\omega \Phi} \cdot \sum_{v=1}^{N} v\right)^{-1}= \\
& =\left(\gamma_{\Phi v} \cdot v\right)^{2} \cdot\left(\beta_{i \Phi} \cdot \sum_{v=1}^{N} v\right)^{-1},
\end{aligned}
$$

Expressing the harmonic components of the electric field through respective parameters of the magnetic field and, conversing the derived result with consideration of expressions (20) and (21), gives the expression relating fractional contribution of the harmonics in the skin flux with corresponding value in the magnetic field intensity:

$$
\begin{aligned}
& \gamma_{\Phi v}=\gamma_{H v} \cdot\left(v \sum_{v=1}^{N} \gamma_{H v}^{2}: v\right)^{-1}= \\
& =\gamma_{H v}\left(v^{-1} \cdot \delta_{\omega H}\right)^{0,5}=\left(\gamma_{H v}: v^{0,5}\right) \cdot \beta_{i \Phi} .
\end{aligned}
$$

Rearranging each of combinations (21), (22), (23) in the same manner gives equations relating high harmonic components of the strongly-varying electromagnetic field parameters with respective equivalence ratios:

$$
\begin{aligned}
& \gamma_{\Phi v}=\left(\gamma_{E v}: v\right) \cdot\left(v \sum_{v=1}^{N} \gamma_{H v}: v\right)^{-1}= \\
& =\gamma_{E v} \cdot\left\{v\left[\sum_{v=1}^{N}\left(\gamma_{E v}: v\right)^{2}\right]^{0,5}\right\}^{-1}=\gamma_{E v} \cdot \delta_{\omega E} \cdot v^{-1} .
\end{aligned}
$$

The relationship between the harmonic components of the electromagnetic field quantities under strongly-varying loads will be defined by the following equations:

$$
\gamma_{H V}=\gamma_{E v} \cdot\left(\sum_{v=1}^{N} \gamma_{E v}^{2} \cdot v^{-1}\right)^{-1}=\gamma_{E v}\left(v^{-1} \cdot \delta_{G E}^{2}\right)^{0,5}=\gamma_{E v} \cdot\left(\beta_{i E} \cdot v^{-1}\right)^{0,5},
$$

$$
\gamma_{H}=\gamma_{\Phi v} \cdot v^{-1}\left(\sum_{v=1}^{N} v \cdot \gamma_{\Phi \nu}^{2}\right)^{-1}=\gamma_{\Phi,}\left(\nu \cdot \delta_{\omega \Phi}^{-1}\right)^{0,5}=\gamma_{\Phi v} \cdot\left(\beta_{\Phi}^{2} \cdot v^{0,5} .\right.
$$

Represented equations enable, basing upon harmonic composition of one of the electromagnetic field quantities, to determine the harmonic composition of other its quantities. These equations allow also to determine the equivalence ratios for the current (tables 1 and 2) as well as skin losses, electric field intensity and skin flux. The equations are suitable for practical engineering calcu- 
lations and researches.

Their findings are shown in table 3.

Further researches are not represented in this work.

Table 3. Expressions relating the high harmonic components of the electromagnetic field quantities in massive ferrous details of structural steels under strongly-varying loads.

\begin{tabular}{|c|c|c|c|}
\hline \multirow{2}{*}{$\begin{array}{c}\text { Parameter to be } \\
\text { investigated }\end{array}$} & \multicolumn{3}{|c|}{ Expressions for the electromagnetic field parameters } \\
\cline { 2 - 4 } & magnetic & electric & skin flux \\
\hline$\gamma_{H v}$ & $H_{v(0)} / H_{\xi(0)}$ & $\left(\delta_{\omega E} \cdot v^{-1}\right)^{0,5} \cdot \gamma_{E v}$ & $\left(\delta_{\omega \Phi}^{-1} \cdot v\right)^{0,5} \cdot \gamma_{\Phi v}$ \\
\hline$\gamma_{E v}$ & $\left(\delta_{\omega H}^{-1} \cdot v\right)^{0,5} \cdot \gamma_{H v}$ & $E_{\nvdash(0)} / E_{\xi(0)}$ & $\left(\delta_{\omega \Phi} \cdot v^{-1}\right)^{0,5} \cdot \gamma_{\Phi v}$ \\
\hline$\gamma_{\Phi v}$ & $\left(\delta_{\omega H} \cdot v^{-1}\right)^{0,5} \cdot \gamma_{H v}$ & $\left(\delta_{\omega E}^{-1} \cdot v\right)^{0,5} \cdot \gamma E$ & $\Phi_{v(0)} / \Phi_{\xi(0)}$ \\
\hline
\end{tabular}

Electromagnetic calculations with use of equivalence ratios for massive ferrous constructive components of electric equipment become more complex due to nonlinear dependence of equivalent magnetic permeability from the magnetic field intensity. They complicate also because of availability of high harmonic, DC, and DC pulsing components. For the case being considered (i.e. electromagnetic field excited by strongly-varying loads) the equivalent magnetic permeability is to be found from averaged magnetic field intensity for the cycle of the first harmonic [8]. Let us consider the physical essence of equivalent magnetic permeability in the electromagnetic field resulted from strongly-varying loads and the procedure for its quantifiable estimation.

Equivalent magnetic permeability is, in general case, integral characteristic of a ferromagnetic. However, for massive ferrous constructive components it is usually defined as averaged characteristic found from the magnetic and electric field intensity measured or calculated on the surface of the body being considered. In the case of electromagnetic field, excited by strongly-varying load, the use of this characteristic is difficult due to availability of high harmonic, DC, and DC pulsing components.

Therefore, in this case the modulus and argument of equivalent magnetic permeability are used that is found from averaged parameters of magnetic field for the first harmonic cycle predetermined on the surface of massive ferrous body being considered. In practical calculations the experimentally measured modulus and argument of equivalent magnetic permeability are usually used or they are found from analytic dependences derived from fundamental $B-H$ curve or magnetic permeability averaged over the first harmonic $[7,8]$. Such calculations, as a rule, lead to complex computations, which are not compensated by accuracy of derived findings required for engineering practice.

In such a way, the equivalent magnetic permeability can be represented by the following expression:

$$
\mu_{\mathrm{eq}}\left(H_{\xi(0)}\right)=\frac{j \sigma}{\omega_{\mathrm{eq}}}\left(\frac{E_{\xi(0)}}{H_{\xi(0)}}\right)^{2} .
$$

The modulus and argument of such characteristic can be expressed through the equivalence ratios in the following form:

$$
\begin{gathered}
\mu_{\text {eq }}\left(H_{\xi(0)} \mid\right)=\frac{\sigma}{\omega_{1} \delta_{\omega E}}\left(\frac{E_{\xi(0)}}{H_{\xi(0)}}\right)^{2}, \\
\arg \mu_{\text {eq }}\left(H_{\xi(0)} \mid\right)=\frac{\pi}{2}-2 \arg \cos \left(\frac{Q_{\xi}\left(\left|H_{\xi(0)}\right|\right)}{E_{\xi(0)} H_{\xi(0)}}\right)
\end{gathered}
$$

The skin losses are determined in this case through the electromagnetic characteristics of the ferromagnetic, magnetic field intensity and equivalence ratio for losses:

$$
Q_{\xi}\left(\left|H_{\xi(0)}\right|\right)=\omega\left(\left|H_{\mathrm{eq}(0)}\right|\right) \cdot \beta_{i \omega}^{2}
$$

In such representation the derived findings are the most acceptable and suitable for the use in practical calculations.

The experimental researches and numerous computations support the possibility to use represented equivalence ratios in engineering calculations. As an example, the fig. 1 shows the equivalence ratios as functions of total harmonic distortion (THD) of the current flowing in the field winding of the samples of structural steels.

The equivalence ratios were evaluated from harmonic composition of the current. In the experiment the high harmonic components was measured with analyzer of spectrum and frequency characteristics and calculated according to the proposed procedure. THD characterizing fractional contribution of high harmonic components in strongly-varying magnetizing current:

$$
K_{f i}=\left[\sum_{v=2}^{N} H_{v}(0) / \sum_{v=1}^{N} H_{v}(0)\right] \cdot 100 \%
$$

was measured with measurer of non-linear distortions. 


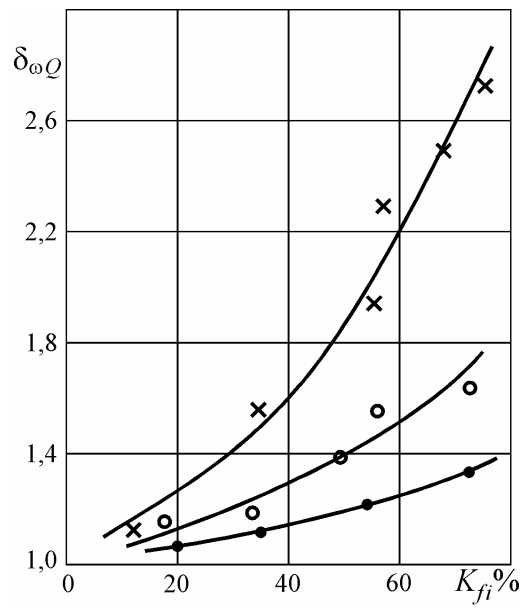

Figure 1.Equivalence ratios as a functions of THD of the exciting current: $\bullet, \mathbf{0}, \mathbf{X}$ - the equivalence ratios for current, losses and frequency, respectively

As it is seen from Figures 1 and 2, the most discordances between calculated and measured findings are observed for the frequency equivalence ratios. It is explained by that during the experiment the frequency did not succeed to be maintained in the predetermined range. The error as for other parameters is significantly lower.

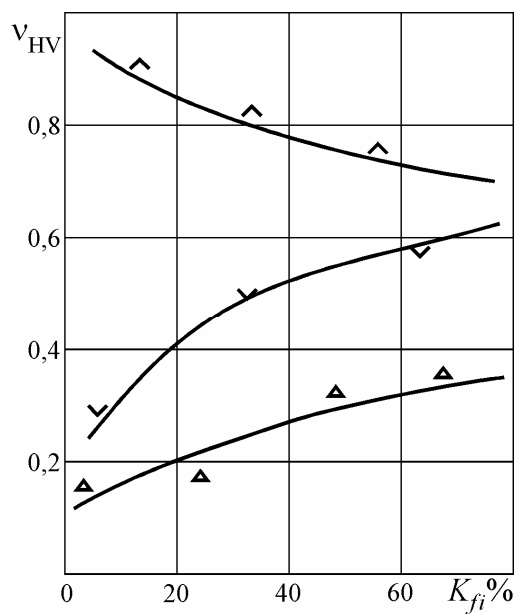

$\boldsymbol{\wedge}, \vee, \mathbf{\Delta}-$ the first, third and fifth harmonics, respectively

Figure 2. IHD as a functions of THD of the exciting current

Numerical findings of equivalence ratios in the range the magnetic field intensity from 258 to $6214 \mathrm{~A} / \mathrm{m}$ at different THD of the exciting current are represented in tables 4-6.

Equivalent parameters are determined so that the equality of skin losses in the sample under sine and nonsine currents was valid:

- while finding the equivalence ratios for the frequency, the exciting current frequency was increased up to equality of the losses under condition of equality of averaged, for the cycle, sine and non-sine magnetic fields;

- while finding the equivalence ratios for the current, the averaged, for the cycle, exciting current was increased up to equality of the losses, but the frequency was selected to be equal to power frequency.

Figure 2 shows behavior of change of the individual harmonic distortion (IHD) for the current as functions of its THD.

Numerous findings represented in tables 4-6 show that error between measured and evaluated equivalence ratios below $5.6 \%$ that is quite acceptable for engineering calculations.

Table 4. Equivalence ratios for non-sine exciting current (THD equals to $33.7 \%$ )

\begin{tabular}{|c|c|c|c|c|c|c|}
\hline \multirow{3}{*}{ 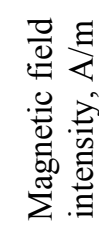 } & \multicolumn{6}{|c|}{ Equivalence ratios, r.u. } \\
\hline & \multicolumn{2}{|c|}{ for current } & \multicolumn{2}{|c|}{ for frequency } & \multicolumn{2}{|c|}{ for losses } \\
\hline & $\cdot \stackrel{\Xi}{\Xi}$ & 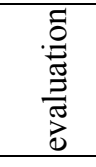 & 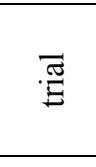 & 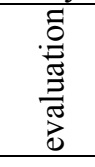 & 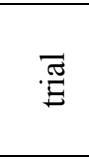 & 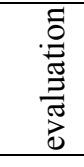 \\
\hline 258,3 & 1,087 & 1,080 & 1,410 & 1,367 & 1,189 & 1,169 \\
\hline 520,1 & 1,083 & & 1,385 & & 1,178 & \\
\hline 785,2 & 1,079 & & 1,387 & & 1,173 & \\
\hline 1321,6 & 1,081 & & 1,384 & & 1,171 & \\
\hline 1745,4 & 1,072 & & 1,370 & & 1,167 & \\
\hline 2693,7 & 1,076 & & 1,393 & & 1,174 & \\
\hline 3501,2 & 1,083 & & 1,397 & & 1,191 & \\
\hline 4371,1 & 1,089 & & 1,384 & & 1,174 & \\
\hline 5243,3 & 1,073 & & 1,378 & & 1,169 & \\
\hline 6214,5 & 1,081 & 1,080 & 1,397 & 1,367 & 1,183 & 1,169 \\
\hline
\end{tabular}

Table 5. Equivalence ratios for non-sine exciting current (THD equals to $53.9 \%$ )

\begin{tabular}{|c|c|c|c|c|c|c|}
\hline \multirow{3}{*}{ 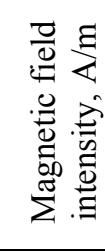 } & \multicolumn{6}{|c|}{ Equivalence ratios, r.u. } \\
\hline & \multicolumn{2}{|c|}{ for current } & \multicolumn{2}{|c|}{ for frequency } & \multicolumn{2}{|c|}{ for losses } \\
\hline & 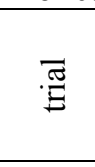 & 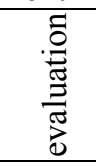 & $\cdot \stackrel{\widetilde{I}}{\Xi}$ & 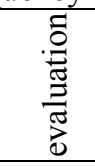 & 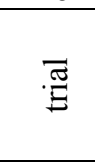 & 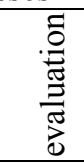 \\
\hline 258,3 & 1,251 & 1,203 & 2,191 & 2,087 & 1,497 & 1,451 \\
\hline 520,1 & 1,249 & & 1,964 & & 1,520 & \\
\hline 785,2 & 1,225 & & 2,037 & & 1,501 & \\
\hline 1321,6 & 1,241 & & 1,975 & & 1,483 & \\
\hline 1745,4 & 1,239 & & 1,941 & & 1,514 & \\
\hline 2693,7 & 1,238 & & 2,053 & & 1,451 & \\
\hline 3501,2 & 1,223 & & 2,041 & & 1,473 & \\
\hline 4371,1 & 1,217 & & 1,971 & & 1,484 & \\
\hline 5243,3 & 1,211 & & 2,036 & & 1,459 & \\
\hline 6214,5 & 1,240 & & 1,980 & & 1,482 & \\
\hline
\end{tabular}


Table 6. Equivalence ratios for non-sine exciting current (THD equals to $70.2 \%$ )

\begin{tabular}{|c|c|c|c|c|c|c|}
\hline \multirow{3}{*}{ 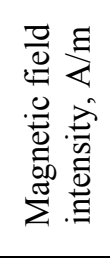 } & \multicolumn{6}{|c|}{ Equivalence ratios, r.u. } \\
\hline & \multicolumn{2}{|c|}{ for current } & \multicolumn{2}{|c|}{ for frequency } & \multicolumn{2}{|c|}{ for losses } \\
\hline & $\cdot \stackrel{\Xi}{\Xi}$ & 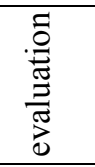 & 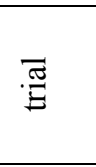 & 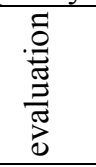 & $\cdot \stackrel{\Xi}{\Xi}$ & 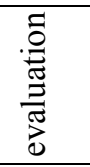 \\
\hline 258,3 & 1,281 & 1,279 & 2,578 & 2,627 & 1,597 & 1,621 \\
\hline 520,1 & 1,317 & & 2,584 & & 1,591 & \\
\hline 785,2 & 1,233 & & 2,591 & & 1,603 & \\
\hline 1321,6 & 1,312 & & 2,601 & & 1,578 & \\
\hline 1745,4 & 1,284 & & 2,607 & & 1,581 & \\
\hline 2693,7 & 1,297 & & 2,604 & & 1,594 & \\
\hline 3501,2 & 1,285 & & 2,597 & & 1,587 & \\
\hline 4371,1 & 1,308 & & 2,610 & & 1,573 & \\
\hline 5243,3 & 1,287 & & 2,627 & & 1,584 & \\
\hline 6214,5 & 1,309 & & 2,598 & & 1,609 & \\
\hline
\end{tabular}

Figures 3 and 4 represent, as an example, time diagrams and oscillograph traces of the skin-effect quantities derived by the way, respectively, computer and physical simulation of non-stationary electromagnetic processes in massive ferrous constructive components under non-sine exciting current having THD equal to $53 \%$.

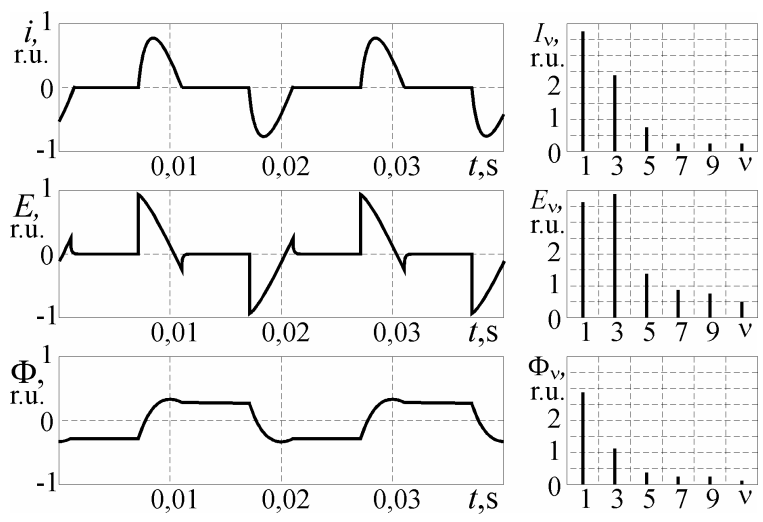

Figure 3. Time diagrams of the current, electric field intensity and magnetic flux derived from computer simulation of electromagnetic processes in ferrous constructive components at $K_{f i}=53 \%$ and corresponding high harmonic composition

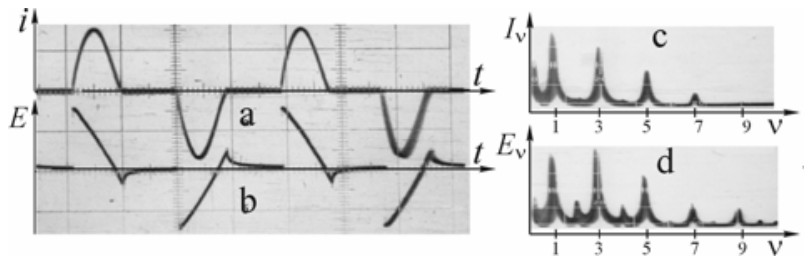

Figure 4. Oscillograph traces of non-sine current (a) and electric field intensity (b) and their spectral composition (c) and (d), respectively, derived from physical simulation of non-stationary skin-effect in massive ferrous details

\section{V.CONCLUSIONS}

1. We have derived the expressions for equivalence ratios of skin-effect parameters that enable:

- to research non-stationary skin-effect in massive ferrous bodies without considering penetration of electromagnetic field into the body;

- to calculate additional and local losses in ferromagnetic constructive components of power-intensive equipment being magnetized by electromagnetic fields resulted from strongly-varying loads taking into account spectral composition of high harmonics;

- to solve engineering problems concerned with selection of most optimal constructions for special-purpose electric and technologic equipment with error no more than $5,6 \%$.

2. The efficiency of practical application of the equivalence ratios consists in that they can be found from predetermined parameters of the magnetic or electric fields or the flux on the surface of ferrous body to be considered or construction to be designed.

3. The truth of represented findings is confirmed by the researches using physical and computer simulations as well as experiments with power-intensive electric equipment supplying arc steel-melting furnaces and drives of rolling mills.

\section{REFERENCE}

[1] Nejman, L.R. (1949). Skin-effect in ferromagnetic bodies. Moskow-Leningrad: Gosenergoizdat, 190 (Rus).

[2] Andreeva, T.A., Berezovskij, A.A., Zinovkin, V.V., Kravchenko A.N., Sisunenko O.I. (1975). Skin losses in massive ferrous bodies under simultaneous magnetization by direct and alternating magnetic fields. Boundary problems of electrodynamics for nonconductive mediums. Proceedings of the Institute of Mathematics of the National Academy of Sciences of Ukraine, Kiev, 5-36. (Rus.).

[3] Zinovkin, V.V., Zozulia, D.V., Kravchenko, A.N., Feshchenko P.P. (1993). Research of transformer losses under strongly varying loads. Technical Electrodynamics, 6, 11-16. (Rus.).

[4] Gzarmeski, L. (1996). Comments on Active Power Flow and Energy Accounts in Electrical Systems With Non-sinusoidal Waveforms and Asymmetry. IEEE Transactions on Power Delivery, 11, 3, 12441250.

[5] Zinovkin, V.V., Rassalskij, A.N. (1998). Special features of electrical-and-technological operating duties of metallurgic complexes. New Materials and Technologies in Metallurgy and Machine Building, 2, 151-154. (Rus.).

[6] Zinovkin, V.V. (1999). Research of the losses in ferrous power transformer tank on the physical models under sine and non-sine currents. New materials and technologies in metallurgy and machine building, 2, 78-83 (Rus.).

[7] Zinovkin, V.V. (1999). Research of skin-effect in 
massive ferrous body under strongly-varying electromagnetic field. Electronics and Electricity, 1, 1421. (Rus.).

[8] Zinovkin, V.V., Rassalskij, A.N. (1999). Normalization of equivalent magnetic permeability for ferromagnetic materials applying in electric machine engineering. Electronics and Electricity, 2, 11-16. (Rus.).

[9] Zinovkin, V.V. (2000). Research of superficial losses in massive structural steels to be magnetized by strongly varying and dc magnetic fields, Works of the Institute of Electrodynamics of the National Academy of Sciences of Ukraine. Power Engineering 2000, 17-30. (Rus.).

[10]Zinovkin, V.V., Zaluzhnyj, M.Y. (2002). Research of non-stationary electromagnetic processes in powerintensive electrical equipment using physical models. Electronics and Electricity, 1, 77-83. (Rus.).

[11]Zinovkin, V.V., Zaluzhnyj, M.Y. (2003). Simulation of non-stationary electromagnetic processes and their special features with use of TOOL BOX POWER SYSTEM of software MATLAB. Trudy Mehzdun. nauch.-techn. konf. "Problemy povyshenia effektivnosti elektromekhanicheskih preobrazovatelej v elekroenergeticheskih sistemah" [Proceedings of Int. Sci.Technical Conf. "Problems of enhancement of electromechanical converters efficiency in power systems"], Sevastopol, SNTU, 75-80. (Rus.).

[12]V.V. Zinovkin, V.V. Kusch, M.Y. Zaluzhnyj (2004). Procedure of Experimental Researches of Physical Processes Using Models of Power Electric Equipment Under Strongly-Varying Currents, Papers of 4th Scientific-and-Technical Conference: "Metrology of Electrical Measurements in Electrical Engineering". RAO UES, VNIIE, 264-268. (Rus.).

[13]Zinovkin, V.V. (2005). Probabilistic parameters of strongly varying loads of power-intensive electro- technological complexes, Works of the Institute of Electrodynamics of the National Academy of Sciences of Ukraine, 1, 136-144. (Rus.).

[14]Zinovkin, V.V. (2005). Non-stationary electromagnetic processes in electric equipment for powerintensive electric technological complexes with strongly-varying behavior of the load. Radio Electronics, Computer Science, Control, 2, 142-148. (Rus.).

[15]Divchuk, T., Yarymbash, D., Yarymbash, S., Kylymnyk, I., Kotsur, M., \& Bezverkhnia, Y. (2018). Approach to determination of no load current of threephase power transformers with plane rods magnetic systems. Electrical Engineering And Power Engineering, 2, 56-66. doi:10.15588/1607-6761-2017-2-6.

[16]Yarymbash, D., Kotsur, M., Yarymbash, S., \& Kotsur, I. (2016). Features of three-dimensional simulation of the electromagnetic fields of the asynchronous motors. Electrical Engineering And Power Engineering, 2, 43-50. doi:10.15588/1607-67612016-2-5.

[17]Divchuk, T., Yarymbash, D., Yarymbash, S., Kylymnyk, I., Kotsur, M., \& Bezverkhnia, Y. (2018). An Adjusting approach to the determination of the permeability functional dependencies of anisotropic cold-rolled electrotechnical steels. Electrical Engineering And Power Engineering, 2, 6-15. doi:10.15588/1607-6761-2018-2-1.

[18] Yarymbash, D., Yarymbash, S., Divchuk, T., \& Kylymnik, I. (2016). The features of magnetic flux distribution of the idling mode of the power transformers. Electrical Engineering And Power Engineering, 2, 5-12. doi:10.15588/1607-6761-2016-2-1.

The article was received 05.11 .2018

\section{ВИЗНАЧЕННЯ ЕКВИВАЛЕНТНІХ ПАРАМЕТРІВ ЕЛЕКТРОМАГНІТНОГО ПОЛЯ У МАСИВНИХ ФЕРОМАГНІТНИХ ДЕТАЛЯХ ЕЛЕКТРИЧНОГО ОБЛАДНАННЯ ПРИ РІЗКОЗМІННИХ НАВАНТАЖЕННЯХ}

\section{ЗІНОВКIH B.B.}

\section{БЛИЗНЯКОВ О.В.} промислових установок Запорізького начіонального технічного університету, Запоріжжя, Україна, е-mail: znvvv@ukr.net;

канд. техн. наук, доиент, доиент кафедри електричних та електронних апаратів Запорізького національного технічного університету, Запоріжжя, Україна, еmail:blizn1953@gmail.com;

Мета роботи. Отримати співвідношення для розрахункового визначення еквівалентних параметрів електромагнітного поля в масивних феромагнітних тілах при різкозмінних навантаженнях.

Методи дослідження. При дослідженні використані методологічні основи теорії поверхневого ефекту у масивних феромагнітних тілах у сполученні з методами математичної фізики, фізичним та комп 'ютерним моделюванням.

Отримані результати. Отримані математичні вирази коефіиієнтів еквівалентності, щзо дозволяють розрахувати основні параметри електромагнітного поля (магнітний потік и втрати) у масивних феромагнітних тілах при різкозмінних навантаженнях. Їх адекватність підтверджена дослідженнями на фізичних и 
комп'ютерних моделях, а також існуючими методами розрахунків додаткових втрат у масивних вузлах енергоємного електротехнічного обладнання спеціального призначення.

Наукова новизна. Вперше встановлені математичні залежності поверхневих втрат та поверхневого магнітного потоку у масивному феромагнітному тілі від несинусоїдальності та спектрального складу вищих гармонік магнітного і електричного полів. Вони є основою для розробки більш точних інженерних методів розрахунку параметрів електромагнітного поля у масивних феромагнітних елементах конструкцій електроустаткування при різкозмінному характері навантаження.

Практична чінність. Використання отриманих виразів коефіцієнтів еквівалентності дозволяє успішно вирімувати інженерні задачі оптимізації елементів конструкиій при проектуванні електротехнічного обладнання для живлення споживачів з різкозмінним характером навантаження.

Ключові слова: електромагнітне поле; різкозмінне навантажееня; масивне феромагнітне тіло; поверхневий ефект; поверхневий магнітний потік; поверхневі втрати; коефіцієнт еквівалентності; склад вищих гармонік.

\title{
ОПРЕДЕЛЕНИЕ ЭКВИВАЛЕНТНЫХ ПАРАМЕТРОВ ЭЛЕКТРОМАГНИТНОГО ПОЛЯ В МАССИВНЫХ ФЕРРОМАГНИНЫХ ДЕТАЛЯХ ЭЛЕКТРООБОРУДОВАНИЯ ПРИ РЕЗКОПЕРЕМЕННЫХ НАГРУЗКАХ
}

\begin{abstract}
ЗИНОВКИН В.В.
д-р техн. наук, профессор, профессор кафедры электропривода и автоматизации промышленных установок Запорожского национального технического университета, Запорожье, Украина, e-mail: znvvv@ukr.net;

БЛИЗНЯКОВ А.В. канд. техн. наук, доцент, доцент кафедры электрических и электронных аппаратов Запорожского национального технического университета, Запорожье, Украина, еmail: blizn1953@gmail.com;
\end{abstract}

Цель работы. Получить соотношения для расчетного определения эквивалентных параметров электромагнитного поля в массивных ферромагнитных телах при резкопеременных нагрузках.

Методы исследования. При исследовании использованы методологические основы теории поверхностного эффекта в массивных ферромагнитных телах в сочетании с методами математической физики, физическим и компьютерным моделированием.

Полученные результаты. Получены математические выражения коэффициентов эквивалентности, позволяюшие рассчитать основные параметры электромагнитного поля (магнитный поток и потери) в массивных ферромагнитных телах при резкопеременных нагрузках. Их адекватность подтверждена исследованиями на физических и компьютерных моделях, а также существующими методами расчетов добавочных потерь 8 массивных узлах энергоемкого электротехнического оборудования специильного назначения.

Научна новизна. Впервые установлены математические зависимости поверхностных потерь и поверхностного магнитного потока в массивном ферромагнитном теле от несинусоидальности и спектрального состава высших гармоник магнитного и электрического полей. Они являются основой для разработки уточненных методов расчета параметров электромагнитного поля в массивных ферромагнитных элементах конструкций электрооборудования при резкопеременном характере нагрузки.

Практическая ченность. Использование полученных выражений коэффициентов эквивалентности позволяет успешно решать инженерные задачи оптимизации элементов конструкций при проектировании электротехнического оборудования для питания потребителей с резкопеременным характером нагрузки.

Ключевые слова: электромагнитное поле; резкопеременная нагрузка; массивное ферромагнитное тело; поверхностный эффект; поверхностный магнитный поток; поверхностные потери; коэффичиент эквивалентности; состав высших гармоник. 